\title{
CUTTING THE PREVALENCE OF PLAGIARISM IN THE DIGITAL ERA: STUDENT TEACHERS' PERCEPTIONS ON PLAGIARISM IN INDONESIAN HIGHER EDUCATION
}

\author{
Maimunah, Lenny Marzulina, Herizal, Muhamad Holandyah \\ State Islamic University of Raden Fatah Palembang, Indonesia \\ E-mail: maimunah@radenfatah.ac.id, hj.lennymarzulina@gmail.com, herizal_uin@ \\ radenfatah.ac.id, muhamadholandyah_uin@radenfatah.ac.id \\ Amirul Mukminin, Robin Pratama, Akhmad Habibi \\ Jambi University, Indonesia \\ E-mail: amirul.mukminin@unja.ac.id, robin.pratama@gmail.com, \\ akhmad.habibi@unja.ac.id
}

\begin{abstract}
It seems that plagiarism has not been seen as misconduct in higher education in some developing countries including in Indonesia which might be affected by cultural, economic, and technological issues. The research aimed at exploring the perceptions of Indonesian student teachers towards plagiarism in four higher education institutions. The research was undertaken as a mixed-method research. Questionnaire and face to face interviews were the instruments to collect data. A paper-based questionnaire was administered to 534 student teachers while face to face interviews were conducted with twenty voluntary participants. The data from the questionnaire were analyzed and presented in the form of percentages, frequencies, and standard deviation while interview data were first analyzed by transcribing the audiotaped interviews into texts, which were then read line-by-line to find and list every significant statement relevant to knowledge of plagiarism definition, research ethic, and research misconduct types, attitudes towards plagiarism, practicing of plagiarism, and reasons of plagiarism among twenty participants. Results showed that most student teachers knew the definition of plagiarism, but they did not know the types of research misconduct. They considered plagiarism as an act of stealing but being unable to avoid in for their study. They tended to do plagiarism because they wanted to save time and they considered about the pressure of their study. Based on the findings of this study, it is important that participants should be required to have more education on plagiarism and its effects and consequences on the ethics of research and education. More strict policies should be implemented to evaluate and supervise plagiarism emerged in Indonesian higher education institutions for undergraduate programs.
\end{abstract}

Keywords: Indonesian higher education, plagiarism in higher education, student teachers, teacher education.

\section{Introduction}

Nowadays, plenty of information technology and knowledge are provided by many providers and companies around the word and are available on widespread sources. The incredible development of information and communication technology has led to a significant improvement in chances for research misconduct which is a plagiarism act (Sarwar, Moin, \& Jaben, 2016). Plagiarism is defined as kidnap (Karami \& Danaei, 2016) derived from Latin 
MAIMUNAH, Lenny MARZULINA, HERIZAL, Muhamad HOLANDYAH, Amirul MUKMININ, Robin PRATAMA, Akhmad HABIBI. Cutting the prevalence of plagiarism in the digital era: Student teachers' perceptions on plagiarism in Indonesian higher education

\section{PROBLEMS \\ OF EDUCATION \\ IN THE $21^{\text {st }}$ CENTURY Vol. 76, No. 5, 2018 \\ 664}

"plagiary." Additionally, plagiarism is termed an act of using others' ideas, methods, or any written words, without having permission and with the intention that might be acknowledged as the work of the deceiver. There are various motives or factors that make people do plagiarism. It can be either an intentional act or unintentional act. The reason could be various including careless acts, laziness in understanding the topic of assignment, limited time to submit papers as well as limited knowledge and education regarding this issue (Choo, Elaine, \& Paull, 2013; Šprajc, Urh, Jerebic, \& Trivan, 2017). It is also deteriorated by the fact that internet is a main tool for students to collect information and copy the writing they want to get compared to books, encyclopedias, and other hardcopy writings. Consequently, this makes plagiarism contagious and dangerous among students especially for students in universities who have much work to do in relation to academic writings (Shrisvastava, 2017). In addition, internet brings large and various amount of information that makes it become indispensable sources of knowledge (Foltyneck, 2014).

To this point, appropriate policies can decrease the number of plagiarism (Sutar \& Khardekar, 2017). For students' assignment and researchers in undergraduate programs, plagiarism can be reduced and prevented by constructing policies made by the universities to detect plagiarism such as Turnitin and I-thenticate (Sutar \& Khardekar 2017). These kinds of tools or software can also be used to improve students' writing skills and build up their abilities to cite and quote (Löfström, Huotari, \& Kupila 2017). Plagiarism is rarely seen as a misconduct in some developing countries (Carnero, Mayta-Tristan, Konda, Mezones-Holguin, Bernabe-Ortiz, Alvarado, \& Canelo-Aybar, 2017) in which this fact might be influenced by cultural and economic factors including in Indonesian higher education. The lack of training, institutional laws and policies, and establishment of writing capabilities in some developing countries can be a factor causing this to happen (Carnero et al., 2017). Further, language may be the biggest problem and challenge for those whose English is not their native language since most sources of writing or articles are written in English (Heitman \& Litewka, 2011). As stated before, plagiarism is a worldwide issue. However, it is merely reported in an exclusive way mostly from developed countries where training and research are used to being implemented in the basic studies and curricula. There are not many studies that publish about plagiarism in developing countries. Given those facts, this research was conducted to fill the gap at examining Indonesian student teachers' perceptions on plagiarism in higher education because the institutional policies on academic plagiarism have not become the focus of the policymakers at university and departmental levels while students' plagiarism happens due to several reasons such as lack of training or lack of information. The findings of this research might give a picture on what higher education in Indonesia should do in order to reduce or prevent students from doing plagiarism although in terms of population and research sites, this research focused on four higher education institutions. The following questions guided this research:

1. What are student teachers' perceptions on the knowledge of plagiarism definition, research ethic, and research misconduct types? What are student teachers' perceptions towards plagiarism?

2. How often have student teachers practiced any plagiarism?

3. What are the reasons for practicing any plagiarism?

\section{Review of Literature}

There are a variety of plagiarism concepts. For example, plagiarism is defined as a continuum ranging from careless paraphrasing to verbatim transcription or texts without crediting sources of paraphrasing (Hawley, 1984). Plagiarism in the context of academia is a scholastic untruthfulness in addition to fabrication and falsification and it is not only an issue in developing countries but also a problem happening around the world (Coughlin, 2015; Ellery, 2008; El-Shinawi et al., 2016; Henning et al., 2013). A report from Ehrich et al. (2016) indicated 
MAIMUNAH, Lenny MARZULINA, HERIZAL, Muhamad HOLANDYAH, Amirul MUKMININ, Robin PRATAMA, Akhmad HABIBI. Cutting the prevalence of plagiarism in the digital era: Student teachers' perceptions on plagiarism in Indonesian higher education

that around $30 \%$ of students plagiarized when researching in their institutions and they tended to be more irresponsible and had less confidence in their writings (Click, 2014). Helgesson and Eriksson (2015), plagiarism is referred to an individual who uses other individual's intellectual products such as ideas, texts and figures, diagrams as well as findings of the research which implied the products as their products. However, the exact number of plagiarism by students is not identified yet.

While there is an agreement about paradigmatic cases of plagiarism, academics, researchers, and scholars have not had a specific agreement on the unified definition of plagiarism in general. Ballor (2015) stated that plagiarism is an act of stealing someone else's work and lying about it. This act divides plagiarism into two parts that are to appropriate someone else's results of work and to copy without citing the original source. However, it is difficult to distinguish plagiarism in practice due to poor knowledge of plagiarism and deliberate intent to obtain unjust advantage. Barrón-Cedeño et al. (2013) argue that plagiarism which is called an academic kidnap can be in the form of plagiarism of ideas, words, texts, and intertwining plagiarism involving primary sources to become his or her own results of work as well as selfplagiarism or duplicate publications in which an author duplicates his or her own work in any way he or she wants.

There have been enormous studies exploring plagiarism in recent decades (Bilić-Zulle et al., 2005; Forinash et al., 2010; Harwood \& Petric, 2012; Jocoy \& DiBiase, 2006). Harwood and Petric (2012) reported studies qualitative in some notable journals which reported that up to a third of the published papers have been informed to be in the category of plagiarism. A report from a medical research informed that $56 \%$ of medical students in USA had committed to plagiarism at least once in their academic opportunity. In another research of survey, the results showed that $40 \%$ of the college students admitted being involved in Internet plagiarisms in 2005 (Jocoy \& DiBiase, 2006) and it had been 30\% rise since 1999.

\section{Why People Plagiarize}

Research on plagiarism in the contexts of students and instructors' perception and attitudes toward plagiarism, scholars have revealed that it frequently happens because of a dense amount of work and insufficient authoring skills (Jenaa \& Sihotanga, 2015; Ehrich et al., 2016), and culture of plagiarism (Adiningrum \& Kutieleh, 2011; Wilkinson 2009). Gender was also an item to influence students' level of plagiarism (Fischer \& Zigmond, 2011; Henning et al., 2013; Jereb, Urc, Jerebic, \& Sprajc, 2018; Ryan et al., 2009). In Southeast Asian countries and China including Indonesia, students may be still requested to learn by rote and restate texts, and take the ideas that teachers teach them. According to Chan (1999), this act could represent and demonstrate the students and instructors' values for those who facilitate and provide information and knowledge.

In addition, regarding perceptions toward learning and knowledge, students in Asian countries and some other countries across the globe are allowed to reproduce knowledge without having acknowledgement from the original makers, writers (Hofstede, 1986). Therefore, they could easily be trapped into plagiarism and infringement (Ehrich, Howard, Mu, \& Bokosmaty, 2014). Indonesian higher education students are at issue of this because they are trained to learn by rote and be unquestioning in their schools of middle high and primary, particularly to their classroom instructors or teachers starting from their first grade. Regarding to reasons for plagiarism, some researchers are related to age, gender, and years of academic experience (Henning et al., 2013; Sagoro, 2013). However, some other researchers found that there was no significant correlation between those factors and the act of plagiarism and research misconduct (e.g., Emmerton et al., 2014; Mohamed et al., 2018).

\author{
PROBLEMS \\ OF EDUCATION \\ IN THE $21^{\text {st }}$ CENTURY \\ Vol. 76, No. 5, 2018 \\ 665
}


MAIMUNAH, Lenny MARZULINA, HERIZAL, Muhamad HOLANDYAH, Amirul MUKMININ, Robin PRATAMA, Akhmad HABIBI. Cutting the prevalence of plagiarism in the digital era: Student teachers' perceptions on plagiarism in Indonesian higher education

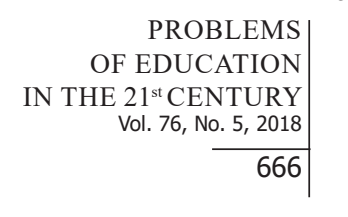

PROBLEMS

$21^{\text {st }}$ CENTURY

666

\section{Plagiarism Types and Ways to Find Them}

Scholars (e.g., Batane, 2010; Biggam, 2008; Ison, 2012; Rabi et al., 2006; Walker, 2010) have recognized various sorts of academic actions which could be categorized and considered to become plagiarism acts and internet as the main tool of plagiarism. For example, Biggam (2008) claimed that plagiarism refers to a copying action of other people's words. Additionally, Walker (2010) categorized three kinds of plagiarism. First, is a sham in which someone copies other original words without placing them into a quotation, although the words are mentioned as a source. Second, is verbatim in which someone copies other people's precise words, but he or she does not give the author a credit or acknowledgment. Third, is purloining in which someone utilizes the paper or work of other students from other places or classes. In a complete examination, Turnitin (2012) who is a well-known plagiarism tracker has a more detailed plagiarism classification from clone, control to aggregator, and re-tweet ranging from copying or utilizing the whole work or papers of other authors to quoting material or sources appropriately but utilizing most portions of sentences and structures.

A research done by Sagoro (2013) tried to propose the improvement of the organizational elements and to unite the control and supervision of all stakeholders including university, departments, colleges, faculty members, and staff. However, the research did not specifically explain on how the technical implementation was done. Other studies done by Jia et al. (2012), Soori et al. (2015), and Shah et al. (2016) were more specific with their studies revealing plagiarism prevention offered for the university lecturers, which is to check directly the students' work using provided tools by universities. In general, there are two major ways to find and check plagiarism; the first one is to ask participants or students or faculty members to fill out questionnaires regarding their activities in line with academia. But this was not very reliable due to a biased answer from the participants (Walker 2010). The second one is to utilize some software to assess the plagiarism, which has been used in many studies and programs (e.g., Batane 2010; Heckler et al., 2013; Ison, 2012; Walker, 2010). Turnitin, for example, gives a comparison to similar words, phrases, or paragraphs from its database. There are 19 languages that can be tracked by this software including Bahasa Indonesia. Turnitin (2014) categorized the index or levels of similarity into 5 levels represented by five distinctive colors from blue, which is no identical text to red meaning over $75 \%$ of plagiarism.

\section{Methodology of Research}

\section{Research Design}

The research was undertaken as a mixed-method research through a quantitative method through a survey approach and a qualitative one (interview). A questionnaire and a face to face interview were used to collect the data. This kind of research design has been appropriate since it describes recent traits of a subject or group, with no intervention or manipulation of the conditions by the subjects. In addition to that, descriptive designs provide valuable summary data when a subject is initially being studied in order to compare large numbers of observations (McMillan \& Schumacher, 2010). A survey adapted from Mohamed, Nohy, and Salah (2018) was deployed to gather data for this research. Survey has often been used in educational research since it can be efficiently applied with relatively little cost and allows generalizability to large populations (Creswell, 2014; McMillan \& Schumacher, 2010). This survey decision for this research was considered a cross-sectional rather than longitudinal research due to the fact that the data were distributed at a single point at once (Creswell, 2014). The questionnaire was distributed to participants in April 2017 to get the data from four universities in the two cities, Palembang (University A with 179 participants and University B with 100 participants) and Jambi (University C with 157 participants and University D with 98 participants). 
MAIMUNAH, Lenny MARZULINA, HERIZAL, Muhamad HOLANDYAH, Amirul MUKMININ, Robin PRATAMA, Akhmad HABIBI. Cutting the prevalence of plagiarism in the digital era: Student teachers' perceptions on plagiarism in Indonesian higher education

\section{Research Sites and Participants}

The target population of this research was all Indonesian student teachers of teacher education in two provinces, South Sumatra and Jambi (see Table 1). The reasons to concentrate on these two provinces since they have similarities in some aspects namely culture, educational system, language, and race as well as the easy access for the research within these areas. Four university lecturers were contacted to facilitate this research. All of them agreed to distribute the questionnaire to their students. A total number of 534 students from four universities in the two cities, Palembang (University A with 179 participants and University B with 100 participants) and Jambi (University C with 157 participants and University D with 98 participants), were the sample of the research. The lecturers were asked to explain the purposes of the questionnaire to the respondents before distributing it. Two public and two private universities were included in this research. This research used the instruments developed by Mohamed, Nohy, \& Salah (2018) and adapted to fit the context in line with the Indonesian teacher education students' perceptions of plagiarism. Some words were adapted so that they fit the cultural contexts in Indonesia.

There were 543 respondents who were Indonesian student teachers at the education programs from four universities returning the questionnaire, university A, university B, university C, and university D. Most of the participants were from university A(179 respondents) and university $C$ (157 respondents). The other respondents were from university B (100) and university D (98). Out of 534 respondents, 313 respondents $(58.61 \%)$ were females while the other 221 respondents $(41.39 \%)$ were males. More than $60 \%$ of the respondents' ages were 20 years old or more. Meanwhile, as many 210 respondents $(39.33 \%)$ were under 20 years old. Most of the respondents, $237(44.38 \%)$ of this research were in the final year while the least respondents, $62(11.61 \%)$ were in the first year. The complete data of the respondents' demographic information were summarized in table 1.

Table 1. Demographic information ( $n$ and \%) of the participants.

\begin{tabular}{llllll}
\hline Institution & University A & University B & University C & University D & Total \\
\hline Respondent & 179 & 100 & 157 & 98 & 534 \\
\hline Gender & & & & & \\
Male & $73(40.78)$ & $41(41)$ & $69(38.55)$ & $38(38.76)$ & $221(41.39)$ \\
Female & $106(59.22)$ & $59(59)$ & $88(56.05)$ & $60(61.22)$ & $313(58.61)$ \\
\hline Age & & & & \\
-20 & $61(34.08)$ & $38(38)$ & $78(49.68)$ & $33(33.67)$ & $210(39.33)$ \\
\pm 20 & $118(65.92)$ & $62(62)$ & $79(50.32)$ & $65(66.33)$ & $324(60.67)$ \\
\hline Major in teacher program & & & & \\
Science & $45(25.14)$ & $38(38)$ & $43(27.39)$ & $27(27.55)$ & $153(28.65)$ \\
Social science & $52(29.05)$ & $28(28)$ & $45(28.66)$ & $35(35.71)$ & $160(29.96)$ \\
Language & $38(21.23)$ & $34(34)$ & $37(23.56)$ & $36(36.73)$ & $145(27.15)$ \\
Primary teacher and pre- & $44(24.58)$ & - & $32(20.38)$ & - & $76(14.23)$ \\
school & & & & \\
\hline Academic year & & & & \\
Year 1 & $24(13.41)$ & $18(18)$ & $20(12.74)$ & - & $82(11.61)$ \\
Year 2 & $37(20.67)$ & $20(20)$ & $25(15.92)$ & - & $153(28.65)$ \\
Year 3 & $47(26.26)$ & $28(28)$ & $43(27.38)$ & $35(35.71)$ & $237(44.38)$ \\
Year +4 & $71(39.66)$ & $34(34)$ & $69(43.95)$ & $63(64.28)$ & \\
\hline
\end{tabular}


MAIMUNAH, Lenny MARZULINA, HERIZAL, Muhamad HOLANDYAH, Amirul MUKMININ, Robin PRATAMA, Akhmad HABIBI. Cutting the prevalence of plagiarism in the digital era: Student teachers' perceptions on plagiarism in Indonesian higher education

PROBLEMS

OF EDUCATION

IN THE $21^{\text {st }}$ CENTURY

Vol. 76, No. 5, 2018

668

\section{Data Collection and Analysis}

Since the research area and site were different, the validation of the questionnaire items were done through face and content validity. Firstly, three professors at the faculty of education of two universities located in two cities of Southern part of Sumatra Island, Jambi and Palembang validated the content of the survey by checking the questions for any scientific errors, and they were requested to have advice in order to improve the adapted questionnaire to suit Indonesian universities context of education. Additionally, suggestions were requested from two linguists regarding the English- Indonesian translation. The final decision of the questionnaire included five sub-categories; demographic information, knowledge of definitions of plagiarism, research ethics, and research misconduct, practicing of plagiarism, and miscellaneous questions on frequency of plagiarism (see Table 2).

Table 2. Questionnaire items' sub-categories and questions.

\begin{tabular}{llll}
\hline Items & Types of questions & No. of statements & Descriptions \\
\hline Q1-Q5 & Closed ended & 5 & $\begin{array}{l}\text { (Demographic information) university, } \\
\text { gender, age, academic year, major }\end{array}$ \\
\hline Q6-Q9 & Closed ended & 4 & $\begin{array}{l}\text { (Knowledge of definition) Definitions } \\
\text { of plagiarism, research ethics, and } \\
\text { research misconduct }\end{array}$ \\
\hline Q10-Q15 & $\begin{array}{l}\text { 5-point Likert scale, (5) strongly } \\
\text { agree, (4) agree, (3) neutral, (2) } \\
\text { agree, (1) strongly disagree }\end{array}$ & 6 & Perceptions towards plagiarism \\
\hline Q16-Q18 & $\begin{array}{l}\text { 5-point Likert scale, (5) always, (4) } \\
\text { often. 3 (sometimes), (2) rarely, (1) } \\
\text { never }\end{array}$ & 3 & Practicing of plagiarism \\
\hline Q19-Q21 & \begin{tabular}{l} 
Open ended \\
\hline
\end{tabular} & 3 & Reasons of plagiarism \\
\hline
\end{tabular}

The final questionnaire was composed of 21 questions. The reliability of the questionnaire was .89 (good). A Google form and hardcopy paper were used in the distribution of the questionnaire, demographic and knowledge information questions were summarized using descriptive statistics and presented in a form of percentage while percentages and frequencies, and standard deviation were used in line with students' perceptions towards plagiarism and practicing of plagiarism. The frequency of the last domain of questionnaire, miscellaneous questions on frequency of plagiarism were counted. Descriptive statistics is summary statistics which describes features of a group of information (Ross, 2010).

In order to get the interview data, participants were invited through asking them to fill a statement on the demographic background form if they were willing or not to take part in the interview. Of all participants, 20 student teachers consisting of 11 female and 9 male student teachers were willing to be interviewed. For the ethical considerations, we masked places, research sites, and their names through the use of pseudonyms. To analyze the interview data, we audiotaped, transcribed verbatim, and carefully analyzed and categorized all of them. The first step that we did was after we interviewed the first participant; we directly audiotaped, transcribed verbatim, and carefully analyzed and categorized all of the interview data (Mukminin \& McMahon, 2013; Mukminin, Kamil, Muazza, \& Haryanto, 2017; Mukminin, Ali, \& Fadloan, 2015). The process was continoued to the last participant. Additionally, all of the researchers read every transcript line-by-line independently and marked relevant statements, then put relevant statements into the categories such as (1) knowledge of plagiarism definition, 
MAIMUNAH, Lenny MARZULINA, HERIZAL, Muhamad HOLANDYAH, Amirul MUKMININ, Robin PRATAMA, Akhmad HABIBI. Cutting the prevalence of plagiarism in the digital era: Student teachers' perceptions on plagiarism in Indonesian higher education

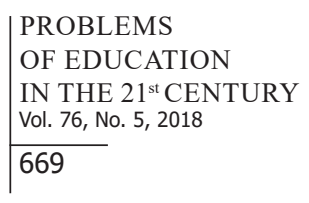

research ethic, and research misconduct types,
of plagiarism, and (4) reasons of plagiarism.

\section{Ethical Considerations}

To protect the research participants who participated in this research, through informed consent form, researchers concealed such as the places, the real names of participants by using pseudonyms. Besides, participation in this research was not mandatory. Participants were allowed to stop participating in this research whenever they wanted. Also, to address the issue of the trustworthiness of interview data (Abrar, Mukminin, Habibi, Asyrafi, Makmur, \& Marzulina, 2018; Habibi, Mukminin, Riyanto, Prasojo, Sulistiyo, Sofwan, \& Saudagar, 2018; Hadiyanto, Mukminin, Arif, Fajaryani, Failasofah, \& Habibi, 2017; Mukminin, Rohayati, Putra, Habibi, \& Aina, 2017), the researchers returned the data and findings to participants in order to get their reactions while thick and rich descriptions are also provided.

\section{Results of Research}

\section{Knowledge of Plagiarism Definition, Research Ethic, and Research Misconduct Types}

Respondents (n.534) were requested to answer four questions regarding their perceptions about plagiarism definition, research ethic, and research misconduct types. In general, there was no difference of these research findings among students from the perspectives of genders, ages, and academic years. Therefore, we did not discuss these factors in our findings. The total number of the respondents who claimed to know the definition of plagiarism was 321 respondents $(60.11 \%)$ while the other 213 respondents $(38.98 \%)$ did not have an idea of the definition. Most of the respondents, $452(84.64 \%)$ thought that plagiarism was a misconduct action. On the other hand, 82 respondents $(15.36 \%)$ thought that it was a correct form of activity. When being asked about research ethic, 319 respondents (59.73\%) affirmed that they knew research ethics while the other 215 respondents $(40.26 \%)$ did not understand research ethics. Last question of this section was to ask the respondents about types of research misconducts where most of the respondents, $413(77.34 \%)$ claimed that they did not know the types. On the contrary, 121 students $(22.66 \%)$ stated that they knew the types. In addition, from the interview data, when we asked participants about their knowledge on plagiarism definition, research ethic, and research misconduct types, we found that not all participants knew these issues. They reported:

I am not sure about my knowledge regarding plagiarism definition, research ethic, and research misconduct types. I even do not know when I plagiarize or not. I think I need more knowledge about it. (Participant 1)

I sometimes forget putting the names of the authors that I use in my work. I do not know if it is right or wrong. (Participant 3)

I always copy and paste sentences from others and I never put their names. I am not sure it is plagiarism. (Participant 7)

The sample of the interview data above indicated that participants had not much knowledge on research ethic and research misconduct types. They should be provided with training on how to avoid plagiarism as they might be teachers and they must be models for their students. 
MAIMUNAH, Lenny MARZULINA, HERIZAL, Muhamad HOLANDYAH, Amirul MUKMININ, Robin PRATAMA, Akhmad HABIBI. Cutting the prevalence of plagiarism in the digital era: Student teachers' perceptions on plagiarism in Indonesian higher education

PROBLEMS

OF EDUCATION

IN THE $21^{\text {st }}$ CENTURY

Vol. 76, No. 5, 2018

670

\section{Perceptions towards Plagiarism}

The respondents were asked to respond to six statements regarding attitudes toward plagiarism. A 5-point Likert scale from strongly agree (5) to strongly disagree (1) was used in this study. The results of the questionnaire regarding student teachers' perceptions towards plagiarism indicated that for Q10 "plagiarism is considered stealing," 343 respondents $(64.23 \%)$ agreed with the statement while the least responses were from 7 respondents $(1.31 \%)$ who strongly disagreed with the statement. Mean for Q10 was 3.78 and standard deviation was 0.83 . Further, for Q11 (Mean: 3.40, SD: 0.83) "There must be a punishment upon plagiarism," the majority of the respondents, 287 (53.75), claimed that they agreed with the statement. On the contrary, only 9 respondents $(1.69 \%)$ strongly disagreed with the statement. The statement which stated Internet has greatly increased plagiarism were supported "agree" by 352 most respondents $(65.92 \%)$ while the least responses which revealed by 7 respondents $(1.31 \%)$ strongly disagreeing with the statement with mean: 3.07 and standard deviation: 1.13. As many 264 respondents $(49.44 \%)$ agreed with a statement "there are less chances of being caught for plagiarism among students," while merely 32 students $(6.00 \%)$ shared their opposite opinion. This statement's mean and SD were 3.07 and 1.13 . The majority of the respondents, $271(50.75 \%)$ considered that when students knew that their friends plagiarized, they tended to do the same and for this statement, the mean was 3.28 with a standard deviation of 1.08. Lastly, for Q15 in this section which statement was "Plagiarism is something unavoidable," the mean was 3.36 and SD was 0.89 where most respondents, 279 $(52.25 \%)$ agreed with it. More complete and detailed data of the students' attitudes toward plagiarism are shown in the Table below.

Table 3. Perceptions towards plagiarism.

\begin{tabular}{|c|c|c|c|c|c|c|c|}
\hline \multirow{2}{*}{ Questionnaire } & \multicolumn{5}{|c|}{ Scale } & \multirow{2}{*}{$M$} & \multirow{2}{*}{$S D$} \\
\hline & 5 & 4 & 3 & 2 & 1 & & \\
\hline Q10. Plagiarism is considered stealing & 70 & 343 & 63 & 51 & 7 & 3.78 & 0.83 \\
\hline Q11.There must be a punishment upon plagiarism & 21 & 287 & 121 & 96 & 9 & 3.40 & 0.88 \\
\hline Q12. Internet has greatly increased plagiarism & 79 & 352 & 54 & 42 & 7 & 3.85 & 0.81 \\
\hline $\begin{array}{l}\text { Q13. There are less chances of being caught for plagiarism } \\
\text { among students }\end{array}$ & 11 & 264 & 74 & 123 & 32 & 3.07 & 1.13 \\
\hline $\begin{array}{l}\text { Q14. When a student know that his/her friends plagiarize, he/ } \\
\text { she tends to plagiarize too }\end{array}$ & 35 & 271 & 76 & 117 & 35 & 3.28 & 1.08 \\
\hline Q15. Plagiarism is something unavoidable & 18 & 279 & 124 & 103 & 10 & 3.36 & 0.89 \\
\hline
\end{tabular}

The findings of theinterviews with participants indicated that their attitude to plagiarism was not good. For example,

I just borrow sentences from others and I do not write the sources [sentences or paragraphs]. But I think it is not plagiarism. I think it is common for every student. Everybody does it. (Participant 20)

You know internet has made everything easy. You can browse a lot of things and find everything that you need. I always collect a lot of sources [sentences or paragraphs] for my assignments. But, since I have collected many sources, I forget where I got them. (Participant 17)

I have never heard some of us get any punishment from copying and pasting for their assignments. It means that what we do is correct. (Participant 9)

The data indicated that lecturers should be aware of their students' work. They have to check their students' work. Additionally, campus authority should make a policy on the issue of plagiarism as the interview data indicated that no strict policy on plagiarism. 
MAIMUNAH, Lenny MARZULINA, HERIZAL, Muhamad HOLANDYAH, Amirul MUKMININ, Robin PRATAMA, Akhmad HABIBI. Cutting the prevalence of plagiarism in the digital era: Student teachers' perceptions on plagiarism in Indonesian higher education

In the practicing of plagiarism section, the students were asked to respond to 3 questions with scales of (5) always, (4) often, (3) sometimes, (2) rarely, and (1) never. They were asked whether they had done any plagiarism in doing their assignment for Q16 where most of them, 363 respondents $(67.98 \%)$ stated that they rarely did that. On the contrary, only 1 respondent $(0.19 \%)$ filled out that she/he always did the plagiarism. The next question with a mean of 4.70 and SD of 0.59 , "how often do you use internet to do your assignments?" were mostly responded "often" by 357 respondents while none of the students claimed that she/he never used internet to do his/her assignment. The last question "Have you ever checked your assignments/projects for plagiarism before submitting them?" was responded by 264 students $(18.54 \%)$ with "sometimes" while merely 5 students $(0.94 \%)$ stated that they never checked their tasks for plagiarism (see Table 4).

Table 4. Practicing of plagiarism.

\begin{tabular}{|c|c|c|c|c|c|c|c|}
\hline Questions & Scale & & & & & $M$ & $S D$ \\
\hline & 5 & 4 & 3 & 2 & 1 & & \\
\hline $\begin{array}{l}\text { Q16. Have you ever done any plagia- } \\
\text { rism in doing your assignment? }\end{array}$ & $1(0.19)$ & $2(0.37)$ & $\begin{array}{l}70 \\
(13.11)\end{array}$ & $\begin{array}{l}363 \\
(67.98)\end{array}$ & $\begin{array}{l}98 \\
(18.35)\end{array}$ & 1.96 & 0.59 \\
\hline $\begin{array}{l}\text { Q17. How often do you use internet } \\
\text { to do your assignments? }\end{array}$ & $\begin{array}{l}109 \\
(20.41)\end{array}$ & $\begin{array}{l}357 \\
(66.85)\end{array}$ & $\begin{array}{l}65 \\
(12.17)\end{array}$ & $3(0.56)$ & - & 4.07 & 0.59 \\
\hline $\begin{array}{l}\text { Q18. Have you ever checked your } \\
\text { assignments/projects for plagiarism } \\
\text { before submitting them? }\end{array}$ & $9(1.69)$ & $\begin{array}{l}99 \\
(18.54)\end{array}$ & $\begin{array}{l}264 \\
(49.44)\end{array}$ & $\begin{array}{l}157 \\
(29.40)\end{array}$ & $5(0.94)$ & 2.90 & 0.76 \\
\hline
\end{tabular}

The findings of the questionnaire were contrary to the findings of our interview. In the questionnaire, 363 respondents $(67.98 \%)$ stated that they rarely did plagiarism on their assignment; however, the results of our interviews indicated that student teachers were doing plagiarism through taking sources from internet without citing the origin of the sources. For example,

I always [use] google [to] help me to find sources for doing my assignments. I think internet is the best machine that helps me to finish my assignments. I just change some sentences or paragraphs before submitting the assignments to my lecturers. [...] I never use any kinds of tools to check my assignment if they are similar to others' work as we do not submit our papers online. (Participant 16)

You know our campus is not really strict on checking our assignments. I do not think we have a tool or machine to check our papers because so far I am just fine with what I have done. (Participant 10)

Additionally, participants in this research admitted that they never checked if their assignments were free from plagiarism or not through the plagiarism system as they were not required to do that before submitting their assignments to their professors.

I am never required to check the similarity level of my assignment. I even do not know about that. (Participant 7)

I will check the similarity of my assignment if I am required to do that. (Participant 5)

The sample from the interview data indicates that theparticipants of this research wanted to avoid doing plagiarism if there is a system that requires them to do that. 
MAIMUNAH, Lenny MARZULINA, HERIZAL, Muhamad HOLANDYAH, Amirul MUKMININ, Robin PRATAMA, Akhmad HABIBI. Cutting the prevalence of plagiarism in the digital era: Student teachers' perceptions on plagiarism in Indonesian higher education

PROBLEMS

OF EDUCATION

IN THE $21^{\text {st }}$ CENTURY

Vol. 76, No. 5, 2018

672

\section{Reasons of Plagiarism}

In the last part of the part, we asked the students about the reasons for doing plagiarism (see Table 8). In the questionnaire, we gave them five general reasons on why someone did plagiarism and they were asked to choose freely with no limitation numbers of reasons. Based on the data, it was revealed that most students, 357 (66.85) informed that they did plagiarism because they wanted to save time. On the other hand, poor research skill was the reason for plagiarism revealed by the least respondents, $112(39.70 \%)$.

Table 5. Reasons of plagiarism.

\begin{tabular}{lcc}
\hline Reasons & Responses (n.534) & Percentage (\%) \\
\hline Time saving & 357 & 66.85 \\
\hline Poor research skill & 112 & 20.97 \\
\hline Pressure of research & 332 & 62.17 \\
\hline Lack of knowledge about plagiarism & 328 & 61.42 \\
\hline $\begin{array}{l}\text { Easy to do (copy and paste from } \\
\text { internet) }\end{array}$ & 226 & 42.32 \\
\hline
\end{tabular}

The data from the interviews also supported the questionnaire findings. Thenterviewees of this research admitted that they plagiarized because of several reasons. They reflected:

You know it is not easy to make good sentences. So, I try to find something on the internet to help me to finish my work. (Participant 16)

Every semester, I have a lot of assignments. Pressure is too much. My ability is limited to finish all of the homework. So, internet is a good helper. But, I do not really copy and paste others' work. (Participant 9)

I wish I could produce my own work in limited time. I want to avoid doing plagiarism, but it is not easy as my ability is limited. (Participant 2)

It is important to note that from the interview data participants in this research wanted to avoid doing plagiarism if they were required to do so. However, they should be supported through facilitating them on how to avoid plagiarizing in academic life.

\section{Discussion}

This research was aimed at exploring the perceptions of Indonesian student teachers on the level of knowledge of plagiarism, attitudes towards plagiarism, practicing plagiarism, and reasons to plagiarism. Student teachers were selectedfrom four universities in Jambi and Palembang, two cities in the southern part of Sumatra Island, Indonesia. Based on the findings of the research, more than 300 respondents claimed that they knew the definition of plagiarism while the other respondents (213 respondents) did not know the definition. This result was not in line with the results from related question "Do you know types of research misconduct" where the majority of the respondents (413) stated that they did not understand the types of research misconduct. This fact leads to the conclusion which proves that even though the respondents ever heard about the term plagiarism, they did not know further explanations about it and had no idea that plagiarism is part of research misconduct. The result is similar to the findings of the studies of El-Shinawi et al. (2016) and Mohamed et al. (2018) which revealed that the respondents of their research did not have appropriate knowledge about both plagiarism and misconduct of research. 
MAIMUNAH, Lenny MARZULINA, HERIZAL, Muhamad HOLANDYAH, Amirul MUKMININ, Robin PRATAMA, Akhmad HABIBI. Cutting the prevalence of plagiarism in the digital era: Student teachers' perceptions on plagiarism in Indonesian higher education

The findings of this research also indicated that regardless of gender and age of the student teachers, their knowledge of plagiarism and research misconduct were in danger and should be provided with good training and information regarding avoiding plagiarism in their academic activities. The findings on this issue are similar to what other researchers found in their research (Emmerton et al., 2014; Eric et al., 2017). However, some other researchers (e.g., Henning et al., 2013; Shakeel et al., 2013) found that male participants of their studies had a higher level of academic dishonesty than female students had. In this research, we also captured students' perceptions towards plagiarism. There were six statements presented to the students. When asked whether plagiarism is an act of stealing and there should be punishment for plagiarists, most respondents agreed with those statements. The findings were similar to what Forinash et al. (2010), Mohamed et al. (2017), and Ryan et al. (2009) found that most of their research participants (more than $80 \%$ ) stated that plagiarism should be punished because it is an act of dishonesty. However, in line with the punishment, most of the students stated that it was difficult for university to know or catch the plagiarism act among the students which was consistent with the previous finding (Mohamed et al., 2017). When we confirmed whether internet had greatly increased plagiarism, more than $65 \%$ of the respondents agreed that the internet influenced the act of plagiarism. There were studies (Rabi et al., 2006; Ryan et al., 2009; Mohamed et al., 2017) that reported that the internet had made plagiarism easier committed by the plagiarists. The majority of the respondents also agreed that when they knew that their friends plagiarized, they would do the same. They also agreed that plagiarism could not be avoided due to some reasons; time saving (66.85\%), pressure of the research $(62.17 \%)$, lack of knowledge about plagiarism $(61.42 \%)$, easy to do by copying and pasting from internet (42.32\%), and poor research skill (20.97\%). These findings were similar to some previous findings from Fischer and Zigmond (2011) and Šprajc et al. (2017) who reported some of the reasons in their studies. In this research, most of the students (rarely, 67.98\%) admitted that they had ever done plagiarism. In addition, they stated that they sometimes (49.4\%) checked their assignment. Regarding these findings, Rettinger and Kramer (2009) and Mohamed et al. (2018) also reported that the students in their research did not always check their assignment.

Moreover, the findings of the interview with twenty participants indicated that they admitted that they plagiarized when doing their assignments or papers due to several reasons such as no strict policies from their campus or professors, no tools or software provided by their campus for checking their work. Participants also realized that what they did was not right, but it seemed that everybody did it. This kind of situation had made them to do the same thing. It was also worsened by the fact that no information that students who did plagiarism had been punished by campus where they studied. However, they reported that they wanted to avoid doing plagiarism if they were provided with a tool for helping them to deal with plagiarism.

Last but not the least, the findings of this researchadd to the body of knowledge and literature on student teachers' knowledge of plagiarism and research misconduct. Particularly, this study focused on the perceptions of Indonesian student teachers towards plagiarism in four higher education institutions. Plagiarism is rarely perceived as a misconduct in some developing countries (Carnero et al., 2017) while not much research has been devoted to study plagiarism in developing countries including Indonesia. The findings of this study indicated that student teachers as the future agents in education had lack of knowledge of plagiarism and research misconduct. This kind of lack of knowledge of plagiarism and research misconduct may be influenced by their culture of learning in which in most Asian countries students may be still demanded to learn by rote and use the ideas and information that teachers teach them. These kinds of behaviors and acts are to show students' respect to their teachers (Chan, 1999) who provide information and knowledge. Additionally, in some Asian countries including Indonesia, students are still allowed to reproduce knowledge without having acknowledgement from the original sources (Hofstede, 1986). This kind of typical learning culture might influence the

\author{
PROBLEMS \\ OF EDUCATION \\ IN THE $21^{\text {st }}$ CENTURY \\ Vol. 76, No. 5, 2018 \\ 673
}


MAIMUNAH, Lenny MARZULINA, HERIZAL, Muhamad HOLANDYAH, Amirul MUKMININ, Robin PRATAMA, Akhmad HABIBI. Cutting the prevalence of plagiarism in the digital era: Student teachers' perceptions on plagiarism in Indonesian higher education

\section{PROBLEMS \\ OF EDUCATION \\ IN THE $21^{\text {st }}$ CENTURY Vol. 76, No. 5, 2018 \\ 674}

perceptions of Indonesian student teachers towards plagiarism in this study. Additionally, their lack of knowledge of plagiarism and research misconduct may be also influenced by their institutional policies in which strict rules, information, training, tools, and procedures to use other work still do not exist to anticipate their plagiarism and research misconduct while during their studies, they are required to write papers as part of their graduation. However, based on the findings of this study, policymakers at university level, faculty members, and department staff should provide student teachers with programs for helping them internalize what the effects and consequences are if they still do plagiarism and research misconduct in future.

\section{Conclusions}

Plagiarism is an issue and considered to be dangerous in higher education. In line with this fact, universities around the world sometimes cover up the issue to protect their universities' brand. Results of our research showed that most student teachers knew the definition of plagiarism, but they did not know the types of research misconduct. They considered plagiarism as an act of stealing, but it is unavoidable in their research. They tended to do plagiarism because they wanted to save time and they considered about the pressure of the research. Students sometimes might not understand that they had done plagiarism or research misconduct because they might not be able to define the definition of plagiarism. This happens because their educational practices such as repetition and memorialization. Due to the fact that students' understanding of integrity and honesty in academic world takes important roles in establishing their positive perceptions toward plagiarism, educational society, system, and stakeholders as well as authorities are recommended to educate young generation about morality and ethics in their research.

Implications for policies and programs related to preventing student teachers from doing plagiarism can be drawn from the findings of this study. First early warning programs, universities and departments should provide new students with clear information what they should and should not do related to plagiarism and research misconduct before starting their programs. They should be provided with strict and clear rules and procedures. This kind of early warning program will make them aware of avoiding plagiarism and research misconduct. Second, training, universities and departments in cooperation with faculty members should provide students with regular training and workshop for avoiding or preventing students from doing plagiarism and research misconduct. Third, student models, learning from role models is great. University and departments should provide new and old students with role models who are successful in their studies without doing any kind of plagiarism and research misconduct during their studies. These role models should be selected and announced through the campus. It may motivate other students to do the same thing. Finally, plagiarism tool, universities and departments should provide students with free plagiarism tool for detecting their plagiarism in their work. However, it is very expensive to buy a plagiarism tool for higher education in developing countries. Universities around the world should cooperate with plagiarism tool companies. Building cooperation with plagiarism tool companies will bring many advantages such as getting low prices of their products or free training.

\section{References}

Abrar, M., Mukminin, A., Habibi, A., Asyrafi, F, Makmur, \& Marzulina, L. (2018). "If our English isn't a language, what is it?" Indonesian EFL student teachers' challenges speaking English. The Qualitative Report, 23 (1), 129-145.

Adiningrum, T. S., \& Kutieleh, S. (2011). How different are we? Understanding and managing plagiarism between east and west. Journal of Academic Language and Learning, 5 (2), 88-98.

Ballor, J. J. (2015). Plagiarism in a digital age. Journal of Market and Morality, 17 (2), 349-352. 
MAIMUNAH, Lenny MARZULINA, HERIZAL, Muhamad HOLANDYAH, Amirul MUKMININ, Robin PRATAMA, Akhmad HABIBI. Cutting the prevalence of plagiarism in the digital era: Student teachers' perceptions on plagiarism in Indonesian higher education

Barrón-Cedeño, A., Vila, M., Martí, M.A., \& Rosso, P. (2013). Plagiarism meets paraphrasing: Insights for the next generation in automatic plagiarism detection. Computational Linguistics, 39 (4), 917 947

Batane, T. (2010). Turning to Turnitin to fight plagiarism among university students. Educational Technology \& Society, 13(2), 1-12.

Biggam, J. (2008). Succeeding with your master's dissertation: A step-by-step guide. London, UK: Open University Press.

Bilić-Zulle, L., Frković, V., Turk, T., Azman, J., \& Petrovecki, M. (2005). Prevalence of plagiarism among medical students. Croatian Medical Journal, 46 (1), 126-131.

Carnero, A. M., Mayta-Tristan, P., Konda, K.A., Mezones-Holguin, E., Bernabe-Ortiz, A., Alvarado, G. F., \& Canelo-Aybar, C. (2017). Plagiarism, cheating and research integrity: Case studies from a master's program in Peru. Science and Engineering Ethics, 23 (4), 1183-1197.

Chan, S. (1999). The Chinese learner - a question of style. Education \& Training, 41 (6), 294-304.

Choo, E., Eng., \& Paul, M. (2013). Reducing the prevalence of plagiarism: A model for staff, students and universities. Issues in Educational Research, 23 (2), 283-298.

Click, A. B. (2014). Taking something that is not your right': Egyptian students' perceptions of academic integrity. Libri, 64 (2), 109-123.

Coughlin, P. E. (2015). Plagiarism in five universities in Mozambique: Magnitude, detection techniques, and control measures. International Journal for Educational Integrity, 11 (2), 1-19.

Ehrich, J., Howard, S. J., Mu, C., \& Bokosmaty, S. (2016). A comparison of Chinese and Australian university students' attitudes towards plagiarism. Studies in Higher Education, 41 (2), 231-46.

Ellery, K. (2008). Undergraduate plagiarism: A pedagogical perspective. Assessment and Evaluation in Higher Education, 33 (5), 507-516.

El-Shinawi, M., Mohamed, K. O., Fouad, Y. A., Fahmy, Y. M., Asar, H. A., Khalil, M. G., Anestidou, L., El-Kamary, S. S., \& Mohamed, M. M. (2016). Assessing the awareness of Egyptian medical students about responsible conduct of research and research ethics: Impact of an educational campaign. Accountability in Research, 23 (4), 199-218.

Elzubeir, M. A., \& Rizk, D. E. (2003). Exploring perceptions and attitudes of senior medical students and interns to academic integrity. Medicine Education, 3 (7), 589-596.

Emmerton, L., Jiang, H., \& McKauge, L. (2014). Pharmacy students' interpretation of academic integrity. American Journal of Pharmaceutical Education, 78 (6), 1-19.

Fischer, B. A., \& Zigmond, M.J. (2011). Educational approaches for discouraging plagiarism. Urologic Oncology: Seminars and Original Investigations, 29 (1), 100-103.

Forinash, A. B., Smith, T. W., Gaebelein, C. J., \& Garavaglia, J. (2010). Differences in self-reported academically dishonest and nondishonest pharmacy students when rating professional dishonesty scenarios. Currents in Pharmacy Teaching and Learning, 2 (2), 100-107.

Habibi, A., Mukminin, A., Riyanto, Y., Prasojo, L. D., Sulistiyo, A., Sofwan, M., \& Saudagar, F. (2018). Building an online community: Student teachers' perceptions on the advantages of using social networking services in a teacher education program. Turkish Online Journal of Distance Education, 19 (1), 46-61.

Hadiyanto, Mukminin, A., Arif, N., Fajaryani, N., Failasofah, \& Habibi, A. (2017). In search of quality student teachers in a digital era: Reframing the practices of soft skills in teacher education. The Turkish Online Journal of Educational Technology, 16 (3), 71-78.

Harwood, N., \& Petric, B. (2012). Performance in the citing behavior of two student writers. Written Communication, 29 (1), 55-103.

Hawley, C. S. (1984). The thieves of Academe: Plagiarism in the university system. Improving College and University Teaching, 32 (1), 35-39.

Heitman, E., \& Litewka, S. (2011). International perspectives on plagiarism and considerations for teaching international trainees. Urologic Oncology: Seminars and Original Investigations, 29 (1), 104-8.

Helgesson, G., \& Eriksson, S. (2015). Plagiarism in research. Medicine, Health Care, and Philosophy, $18(1), 91-101$.

Henning, Marcus, A., Ram, S., Malpas, P., Shulruf, B., Kelly, F., \& Hawken, S.J. (2013). Academic dishonesty and ethical reasoning: Pharmacy and medical school students in New Zealand. Medical Teacher, 35 (6), 1211-1217.

Hofstede, G. (1986). Cultural differences in teaching and learning. International Journal of Intercultural Relations, 10 (3), 301-320.
PROBLEMS

OF EDUCATION

IN THE $21^{\text {st }}$ CENTURY

Vol. 76, No. 5, 2018 
MAIMUNAH, Lenny MARZULINA, HERIZAL, Muhamad HOLANDYAH, Amirul MUKMININ, Robin PRATAMA, Akhmad HABIBI. Cutting the prevalence of plagiarism in the digital era: Student teachers' perceptions on plagiarism in Indonesian higher education

\section{PROBLEMS \\ OF EDUCATION \\ IN THE $21^{\text {st }}$ CENTURY Vol. 76, No. 5, 2018 \\ 676}

Ison, D. C. (2012). Plagiarism among dissertations: Prevalence at online institutions. Journal of Academic Ethics, 10 (3), 227-236.

Jenaa, Y., \& Sihotanga, K. (2015). Bwinning is everything as the basis of academic misconduct among Indonesian students. Sociology, 5 (2), 157-162.

Jereb, E., Urc, M., Jerebic, J., \& Sprajc, P. (2018). Gender differences and the awareness of plagiarism in higher education, Social Psychology of Education, 21 (2), 409-426.

Jia, S., Liu, D., Zhang, L., \& Liu, C, (2012). A Research on Plagiarism Detecting Method Based on XML Similarity and Clustering. In Y. Wang, \& X. Zhang (Eds.), Internet of Things: International Workshop, IOT 2012, Changsha, China, August 17-19, 2012. Proceedings (619-626). Berlin, Heidelberg: Springer Berlin Heidelberg.

Jocoy, C. L., \& DiBiase, D. (2006). Plagiarism by adult learners online: A case research in detection and remediation. The International Review of Research in Open and Distributed Learning, 7 (1), 1-15.

Karami, M., \& Danaei, G.H., (2016). A brief review of plagiarism in medical scientific research papers. Pharmaceutical and Biomedical Research, 2 (2), 1-8. doi:10.18869/acadpub.pbr.2.2.1.

Löfström, E., Huotari, E., \& Kupila, P. (2017). Conceptions of plagiarism and problems in academic writing in a changing landscape of external regulation. Journal of Academic Ethics, 15 (3), 77-92.

Mohamed, M, E., Mohy, N., \& Salah, S. (2018): Perceptions of undergraduate pharmacy students on plagiarism in three major public universities in Egypt. Accountability Research, 25 (2), 109-124.

Mukminin, A., Kamil, D., Muazza, M., \& Haryanto, E. (2017). Why teacher education? Documenting undocumented female student teachers' motives in Indonesia: A case study. The Qualitative Report (USA), 22 (1), 309-326.

Mukminin, A., Rohayati, T., Putra, H. A., Habibi, A., \& Aina, M. (2017). The long walk to quality teacher education in Indonesia: Student teachers' motives to become a teacher and policy implications. Elementary Education Online, 16 (1), 35-59.

Mukminin, A., Ali, Rd. M., \& Fadloan, M. J. (2015). Voices from within: Student teachers' experiences in english academic writing socialization at one Indonesian teacher training program. The Qualitative Report, 20 (9), 1394-1407.

Mukminin, A., \& McMahon, B.J. (2013). International graduate students' cross-cultural academic engagement: Stories of Indonesian doctoral students on American campus. The Qualitative Report, 18 (69), 1-19.

Murley, L. D., Jukes, P., \& Stobaugh, R. (2013). Raising expectations for pre-service teacher use of technology. International Journal of Humanities and Social Science, 3 (14), 1-8.

Rabi, S. M., Patton, L. R., Fjortoft, N., \& Zgarrick, D. P. (2006). Characteristics, prevalence, attitudes, and perceptions of academic dishonesty among pharmacy students. American Journal of Pharmaceutical Education, 7 (4), 73.

Rettinger, D. A., \& Kramer, Y. (2009). Situational and personal causes of student cheating. Research in Higher Education, 50 (3), 293-313.

Ryan, G., Bonanno, H., Krass, I., Scouller, K., \& Smith, L. (2009). Undergraduate and postgraduate pharmacy students' perceptions of plagiarism and academic honesty. American Journal of Pharmaceutical Education, 73 (6), 105.

Sagoro, E. M, (2013). Pensinergian mahasiswa, dosen, dan lembaga dalam pencegahan kecurangan akademik mahasiswa akuntansi [The synergistic efforts among students, lecturers, and institutions in the prevention of academic fraud among accounting students]. Jurnal Pendidikan Akuntansi Indonesia, 11 (2), 54-67.

Sarwar, M., Moin, M., \& Jabeen, M. (2016). Role of plagiarism detecting software in reducing academic dishonesty at M.Phil level. The Dialogue, 11 (4), 414-426.

Shah, N., Modha, S., \& Dave, D, (2016). Differential weight-based hybrid approach to detect software plagiarism. In C. S. Satapathy, A. Joshi, N. Modi, \& N. Pathak (Eds.), Proceedings of international conference on ICT for sustainable development: ICT4SD 2015 Volume 2 (pp. 645-653). Singapore: Springer Singapore.

Šprajc, P., Urh, M., Jerebic, J., \& Trivan, D. (2017). Reasons for plagiarism in higher education. Organizacija, 50 (1), 33-45.

Sutar, D. B., \& Khardekar, B. B. (2017). Use of Turnitin by faculty members and its relevance to quality of research: A case research of Shivaji university. Kolhapur, 7 (1), 1-4.

Walker, J. (2010). Measuring plagiarism: Researching what students do, not what they say they do. Studies in Higher Education, 35 (1), 41-59.

Wilkinson, J. (2009). Staff and student perceptions of plagiarism and cheating. International Journal of Teaching and Learning in Higher Education, 20 (2), 98-105. 
MAIMUNAH, Lenny MARZULINA, HERIZAL, Muhamad HOLANDYAH, Amirul MUKMININ, Robin PRATAMA, Akhmad HABIBI. Cutting the prevalence of plagiarism in the digital era: Student teachers' perceptions on plagiarism in Indonesian higher education

\begin{tabular}{|c|c|}
\hline Maimunah & $\begin{array}{l}\text { Doctor in Educational Management, Associate Professor, Arabic Education } \\
\text { Department, Faculty of Tarbiyah and Teaching Sciences, State Islamic Univer- } \\
\text { sity of Raden Fatah Palembang, South Sumatra 30126, Indonesia. } \\
\text { E-mail: maimunah@radenfatah.ac.id }\end{array}$ \\
\hline Lenny Marzulina & $\begin{array}{l}\text { M.Pd., Lecturer, English Education Department, Faculty of Tarbiyah and } \\
\text { Teaching Sciences, State Islamic University of Raden Fatah Palembang, South } \\
\text { Sumatra 30126, Indonesia. } \\
\text { E-mail: hj.lennymarzulina@gmail.com }\end{array}$ \\
\hline Herizal & $\begin{array}{l}\text { M.A., Lecturer, English Education Department, State Islamic University of } \\
\text { Raden Fatah Palembang, Indonesia. } \\
\text { E-mail: herizal_uin@radenfatah.ac.id }\end{array}$ \\
\hline Muhamad Holandyah & $\begin{array}{l}\text { M.Pd., Lecturer, English Education Department, State Islamic University of } \\
\text { Raden Fatah Palembang, Indonesia. } \\
\text { E-mail: Muhamadholandyah_uin@radenfatah.ac.id }\end{array}$ \\
\hline Amirul Mukminin & $\begin{array}{l}\text { PhD, Associate Professor, the Graduate School, Jambi University, Jambi, } \\
\text { 36361, Indonesia. } \\
\text { E-mail: amirul.mukminin@unja.ac.id } \\
\text { https://orcid.org/0000-0002-6806-1315 }\end{array}$ \\
\hline Robin Pratama & $\begin{array}{l}\text { M.Pd., Lecturer, Faculty of Teacher Training and Education, Jambi University, } \\
\text { Jambi, } 36361 \text {, Indonesia. } \\
\text { E-mail: robin.pratama@gmail.com }\end{array}$ \\
\hline Akhmad Habibi & $\begin{array}{l}\text { M.Pd., Lecturer, Faculty of Teacher Training and Education, Jambi University, } \\
\text { Jambi, 36361, Indonesia. } \\
\text { E-mail: akhmad.habibi@unja.ac.id } \\
\text { Website: https://orcid.org/0000-0001-7687-2858 }\end{array}$ \\
\hline
\end{tabular}

